\title{
The Application of X-rays for an Electrodeposition of Composite Coatings with Modified Structures and Properties
}

\author{
Natalia Valko ${ }^{1}$, Wiktoria Evstigneeva ${ }^{1}$, Victor Anishchik ${ }^{2}$, Vitalii Bondariev ${ }^{3}$, Pawel Okal ${ }^{3}$ \\ and Tomasz N. Koltunowicz ${ }^{3, * \text { (D) }}$ \\ 1 Department of General Physics, Yanka Kupala State University of Grodno, 22, Ozheshko Str., \\ 230023 Grodno, Belarus; n.valko@grsu.by (N.V.); evstigneeva_vp@grsu.by (W.E.) \\ 2 Department of Solid State Physics, Belarusian State University, 4, Nezavisimosti Ave., 220030 Minsk, Belarus; \\ anishchik@bsu.by \\ 3 Department of Electrical Devices and High Voltage Technology, Lublin University of Technology, 38d, \\ Nadbystrzycka Str., 20-618 Lublin, Poland; v.bondariev@pollub.pl (V.B.); p.okal@pollub.pl (P.O.) \\ * Correspondence: t.koltunowicz@pollub.pl; Tel.: +48-81-538-47-13
}

Citation: Valko, N.; Evstigneeva, W.; Anishchik, V.; Bondariev, V.; Okal, P.; Koltunowicz, T.N. The Application of $X$-rays for an Electrodeposition of Composite Coatings with Modified Structures and Properties. Energies 2021, 14, 4913. https://doi.org/ 10.3390/en14164913

Academic Editor: Luca Pasquini

Received: 6 July 2021

Accepted: 8 August 2021

Published: 11 August 2021

Publisher's Note: MDPI stays neutral with regard to jurisdictional claims in published maps and institutional affiliations.

Copyright: (C) 2021 by the authors Licensee MDPI, Basel, Switzerland. This article is an open access article distributed under the terms and conditions of the Creative Commons Attribution (CC BY) license (https:// creativecommons.org/licenses/by/ $4.0 /)$.

\begin{abstract}
Experimental studies of the effect of X-rays on the process of electrolytic deposition of composite coatings are reviewed in this paper. Particular emphasis will be on the applications of X-rays for both the modification of a structure and the mechanical characteristics of galvanic coatings. In particular, this research investigates the $\mathrm{Co} / \mathrm{SiO}_{2}$ coatings deposited from aqueous solutions under the effect of $\mathrm{X}$-rays. The results of extensive investigations into the dispersing ability of electrolytes with $\mathrm{SiO}_{2}$ nanoparticles and a mass rate of composite coatings $\mathrm{Co} / \mathrm{SiO}_{2}$ indicates that the method of electroplating under the effect of $\mathrm{X}$-rays during the process results in the intensification of diffusion in the electrolyte volume and creates dense, uniform coatings. This research demonstrates that exposure of an electrolytic cell to X-rays during the electroplating process of $\mathrm{Co} / \mathrm{SiO}_{2}$ results in an orienting effect on the formation of crystal grains and allows for the creation of dense, morphology uniform coatings with increased hardness and improved adhesion.
\end{abstract}

Keywords: composite coatings; X-rays irradiation; radiolysis; nanoparticles; structure; properties

\section{Introduction}

Electroplated composite coatings with included nanoparticles occupy an important place among the various types of protective coatings and thin nanocomposite films. Electroplating is widely used in different fields of industry on objects of various sizes. Today, methods of electrolytic plating used in industry are significantly cheaper when compared with different methods of covering objects, such as plasma-assisted chemical vapor deposition [1-5], ion implantation [6,7], ion-beam [8,9] and magnetron sputtering [10,11], or other plasma techniques and chemical methods [12-14] which can be used primarily for the protection of small objects.

The formation of composite coatings with included nanoparticles that have the required surface morphology, microstructure and excellent properties across different applications depends on the composition of a reaction medium, electrodeposition conditions and modes. In most instances, it also depends on the sedimentation stability of nanoparticles in an electrolyte. The most commonly employed method for supporting the sedimentation stability of nanoparticles is by means of different additives which prevent the coagulation of nanoparticles. The most visible disadvantage of employing additives is that it results in a change in the chemical composition of electrolytes, leading to narrowed range of working current densities of electrodeposition. In light of this, it is important to note that additives can contribute to form composite coatings with a deterioration of qualities and properties [15-17]. 
The effect of external factors on the formation of composite coatings with the required properties are widely applied, alongside multipurpose electroplating of electrolytes using insoluble suspended nanoparticles [18,19].

The well-known method for obtaining deposition composite coatings with included nanoparticles involves creating a suspended aqueous solution by means of electrodeposition under ultrasonic vibrations. The application of an ultrasonic field for suspending liquid and manufacturing of new materials has a long history and indicates broad prospects in the microstructure control and performance improvement for electroplated metals and alloys. Despite abundant research on the sedimentation stability of electrolytes containing nanoparticles with the help of ultrasonic technologies, the refinement mechanism of ultrasonic treatment during the electrodeposition process is still controversial. Of particular note is the surprising laboriousness and increasing energy consumption that is involved in the implementation of ultrasounds in the technological process. This implementation is associated with the need to prevent the formation of standing sound waves caused by reflecting ultrasonic waves transferring back and forth from the surface of a cathode. The formation of standing waves also causes a decrease in diffusion and the net ion flow to the cathode surface, promoting the accumulation of nanoparticles under the source of ultrasonic vibrations. It is obvious that the accumulation of nanoparticles near the ultrasonic vibrations source leads to coagulation of insoluble particles, to a reduction of the dispersing ability and to the concomitant deterioration of the operational properties of coatings and, subsequently, leads to a decrease in the economic efficiency of the technological process [20].

In order to overcome these limitations, the present research focuses on the process of electroplating composite coatings with nanoparticles under the effect of X-rays [21-23]. The benefits and uses of this process make this method an appealing option for a lot of industries. The main mechanisms of X-ray irradiation of suspended electrolytes are based on the formation of active and mobile radiolysis products in the irradiated electrolyte, which contribute to a natural mixing of electrolyte, leading to an increase in its dispersing ability and to an intensification of the electroplating process. This makes it possible to form dense, fine-grained coatings that are uniform in thickness, with improved operational properties [24].

Of particular interest are electroplated Co-coatings that are used in the manufacturing of reflectors, mirrors, and jewelry. The high abrasion resistance and the lower cost of producing electroplated Co-coatings enables its use it in more applications.

The main aim of this study is to undertake an experimental investigation on the effect of X-rays on the process of electrochemical deposition of composite coatings $\mathrm{Co} / \mathrm{SiO}_{2}$, underlining the application of X-rays for the modification of microstructural characteristics and mechanical performances of protective electrodeposited coatings.

\section{Experimental}

$\mathrm{Co} / \mathrm{SiO}_{2}$ composite coatings were electrodeposited from the additive-free sulfate electrolyte with following composition: $\mathrm{CoSO}_{4} \cdot 7 \mathrm{H}_{2} \mathrm{O}-200 \mathrm{~g} / \mathrm{dm}^{3}, \mathrm{H}_{3} \mathrm{BO}_{3}-15 \mathrm{~g} / \mathrm{dm}^{3}$ and $\mathrm{NaCl}-10 \mathrm{~g} / \mathrm{dm}^{3}$. The concentration of $\mathrm{SiO}_{2}$ nanoparticles was $0.5 \mathrm{~g} / \mathrm{dm}^{3}$ and $1 \mathrm{~g} / \mathrm{dm}^{3}$. Deposition was performed with a preliminary reverse over a duration of $5 \mathrm{~min}$. Lowcarbon steel with a carbon content of $0.05-0.12 \%$ was used as a substrate. Before plating, all substrates were polished with the help of a polishing machine, BAINPOL VT Auto, in order to prepare samples with an average roughness $0.05 \mu \mathrm{m}$. Coatings were electrodeposited for $1 \mathrm{~h}$ in the X-ray field (Peks $=100 \mathrm{R} / \mathrm{h}$ ) at a controlled temperature of $23{ }^{\circ} \mathrm{C}$ [25].

Electroplating was carried out in the thermostatic bath with two cells of $100 \mathrm{~mL}$ (Figure 1). One cell was used for depositing coatings under X-rays' irradiation, effecting the electrolyte directly. Another cell was used for the deposition of reference coatings.

The current densities were chosen in the range from 1 to $3 \mathrm{~A} / \mathrm{dm}^{2}$. Coatings formed in the X-ray field (the irradiated samples (Irr)) and coatings formed without exposure to $X$-rays (the reference samples (Ref)) were compared in order to estimate the structural 
variations caused by X-ray exposure. The thickness was measured with a MTTs-3 m (Minsk, Belarus). The mass gain and thickness of the $\mathrm{Co} / \mathrm{SiO}_{2}$ coatings were determined by taking the average of 10 measurements ( 10 samples). The surface morphology and elemental composition were studied by means of a JSM-5610 LV scanning electron microscope equipped with the EDX JED-2201 chemical analysis system (JEOL, Akishima, Japan). The accelerating voltage was recorded as $20 \mathrm{keV}$. The estimated depth range of electrons did not exceed $0.98 \mu \mathrm{m}$. The energy resolution of the detector was approximately $0.137 \mathrm{keV}$. The phase $\mathrm{Co} / \mathrm{SiO}_{2}$ composition was studied by X-ray diffraction (XRD) with the help of a DRON-3M diffractometer in the $\mathrm{CuK} \alpha$ radiation (Burevestnik, St. Petersburg, Russia). The microhardness of the coating surfaces were measured with a CASON-59 HV microhardness tester (Jinan Kason Testing Equipment Co, Jinan City, Shandong Province, China). The adhesion of $\mathrm{Co} / \mathrm{SiO}_{2}$ coatings to the steel was investigated using the scratch method, which is based on the application of a scratch grid to the surface of testing coatings. The adhesion tests were carried out in accordance with the Interstate standard [26]. The dispersing ability of the electrolytes was studied with the help of a Moler's cell [27]. The Moler's cell has a rectangular shape with a collapsible cathode block. The cathode block consists of 10 indifferent aluminum cathodes. The main characteristic of the Moler's cell is that the cathode space is separated from the anode space with a non-conductive partition. Between the partition and one of the side bath walls there must be a space of 1 or $2 \mathrm{~mm}$. In this case, the slight gap is a non-polarizable anode that does not cause concentration changes in a solution. The advantage of the Moler's cell is that the cathode current distribution in it does not depend on the shape or the anode location.

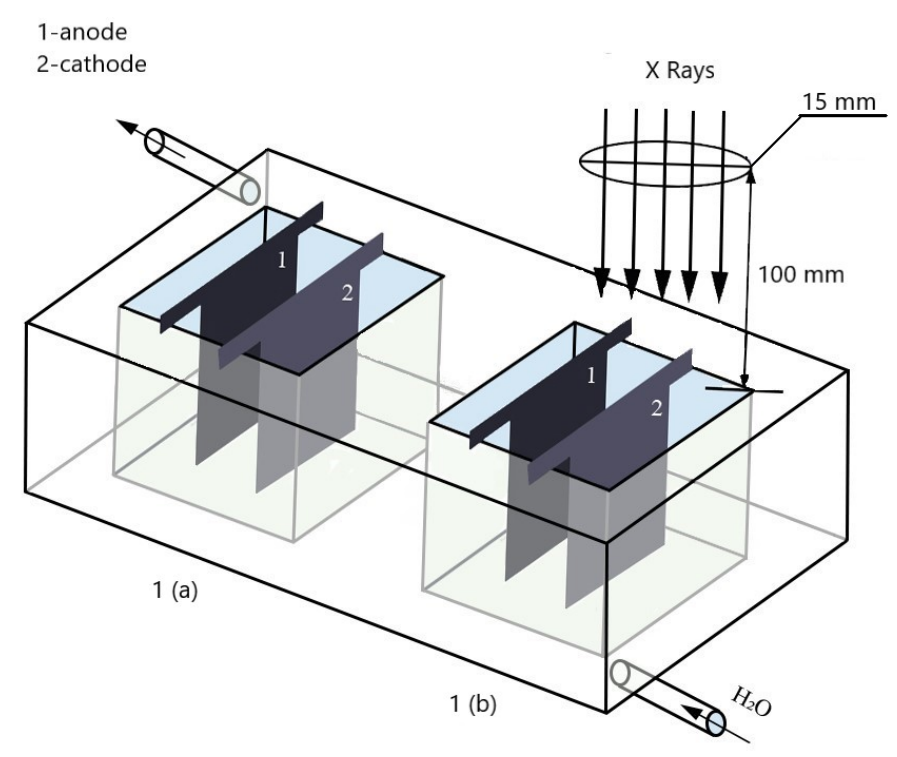

Figure 1. Schematic illustration of plating bath under effect of X-ray: (a) cell for deposition of reference sample; (b) cell for deposition of irradiated sample.

The value of the dispersing ability was computed by measuring the mass distribution on all Al-cathodes according to the Unified System of corrosion and ageing protection of the galvanic coating. The designation of the dispersing ability of electrolytes was determined during the creation of coverings [27]. The relative error of the method did not exceed 5\%.

\section{Results}

Figure 1 shows the SEM images of surface morphology and cross sections of $\mathrm{Co} / \mathrm{SiO}_{2}$ composite coatings, formed under the effect of $\mathrm{X}$-rays, and the reference sample formed from electrolytes with $\mathrm{SiO}_{2}$ concentration of $0.5 \mathrm{~g} / \mathrm{dm}^{3}$. As shown in Figure 1a, the reference sample formed without irradiation is characterized by needle-shaped crystallites normally oriented to the substrate plane and by coarse and inhomogeneous grains ori- 
ented lengthwise (parallel) to the substrate plane. This structure is typical for a cobalt microstructure [24]. By contrast, a detailed examination of micrographs as seen in Figure $1 \mathrm{~b}$ reveals that the irradiated samples differ from the geometry surface with crystalline grains only parallel directed to the substrate. The observed differences in the microstructure of irradiated and reference samples is caused by destruction of the primary structure of an electrolyte affected by $\mathrm{X}$-rays and radiolysis transformations.

Based on a comparative analysis of Figures 2 and 3, it is obvious that well visible normally oriented grains on the references samples gradually become smaller (Figure 3a) and are almost entirely eliminated on the surface of the irradiated $\mathrm{Co} / \mathrm{SiO}_{2}$ coatings (Figure $3 b$ ). It should be noted that coatings demonstrated on Figure 2 were formed from an electrolyte with a $\mathrm{SiO}_{2}$ concentration of $1 \mathrm{~g} / \mathrm{dm}^{3}$.

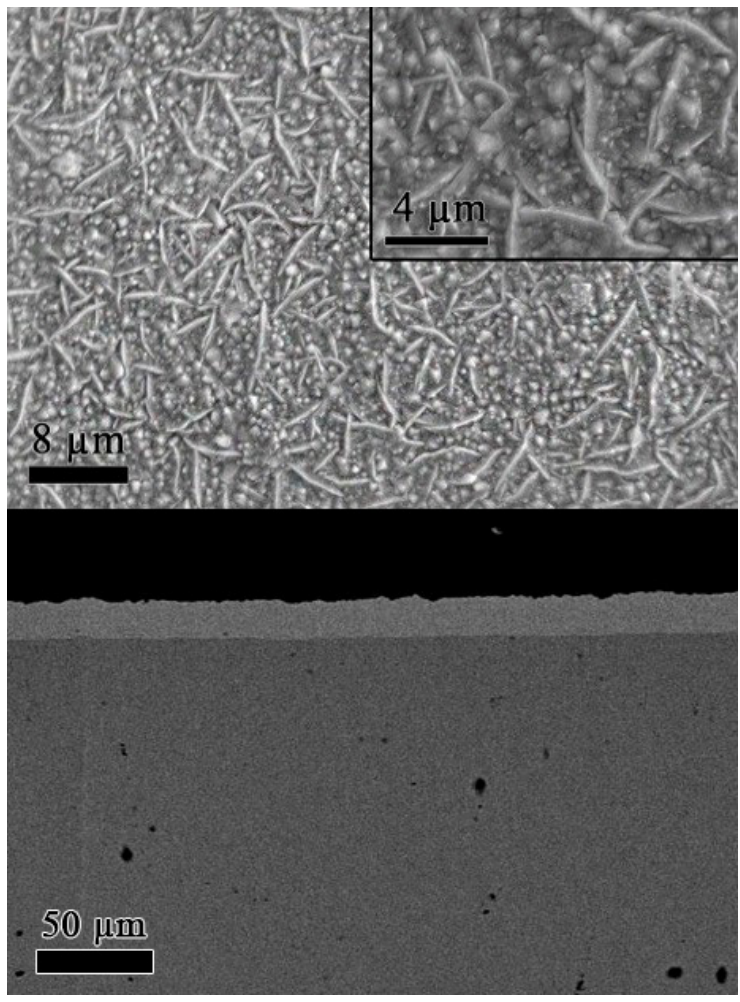

(a)

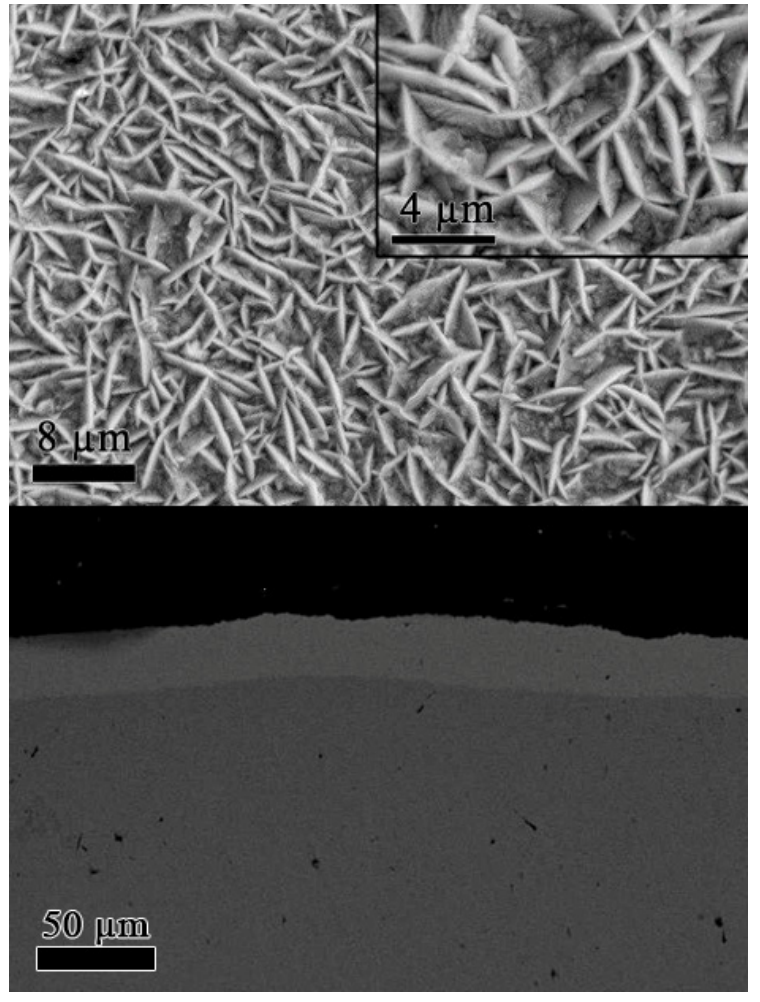

(b)

Figure 2. SEM images of surface and cross sections of $\mathrm{Co} / \mathrm{SiO}_{2}$ formed at $2 \mathrm{~A} / \mathrm{dm}^{2}$ current density from electrolyte at $0.5 \mathrm{~g} / \mathrm{dm}^{3} \mathrm{SiO}_{2}$ nanoparticles: (a) reference sample; (b) irradiated sample.

It should be noted that the $\mathrm{Co} / \mathrm{SiO}_{2}$ coatings deposited from an electrolyte with $\mathrm{SiO}_{2}$ nanoparticles of $1 \mathrm{~g} / \mathrm{dm}^{3}$ are characterized with more developed surface geometry in comparison to coatings which were deposited from the electrolyte with an $\mathrm{SiO}_{2}$ concentration of $0.5 \mathrm{~g} / \mathrm{dm}^{3}$. As such, it can be suggested that the structure of $\mathrm{Co} / \mathrm{SiO}_{2}$ coatings is affected by the $\mathrm{SiO}_{2}$ concentration. However, it is clear that the reference deposit consists of two types of crystalline grains: normal and parallel oriented to the substrate plane.

A comparative analysis of the irradiated and reference cross sections of composite coatings $\mathrm{Co} / \mathrm{SiO}_{2}$ (Figure 2) allows us to conclude that the rate of deposition under the effect of $X$-radiation is significantly higher and that nonporous dense coatings are formed in the X-ray's field.

Therefore, unlike the traditional electroplating process, the interfusion of the electrolyte with radical particles in the X-ray irradiated electrolyte prevents the formation of cohesive contacts between $\mathrm{SiO}_{2}$ nanoparticles and reduces the likelihood of coagulation and sedimentation. Due to this, the $\mathrm{SiO}_{2}$ nanoparticles transfer to the cathode surface, 
where they are plated by a reduced metal, forming their own finely dispersed agglomerate with an increased content of nanoparticles and with improved operational properties [21].

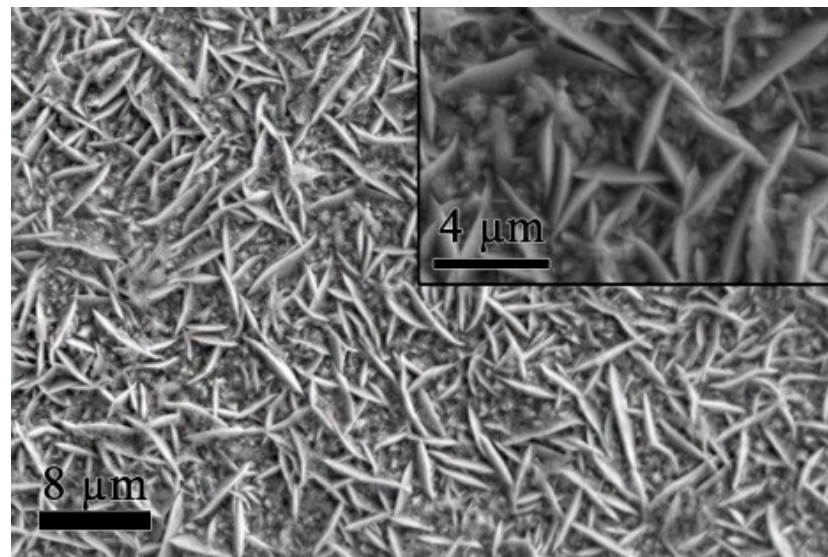

(a)

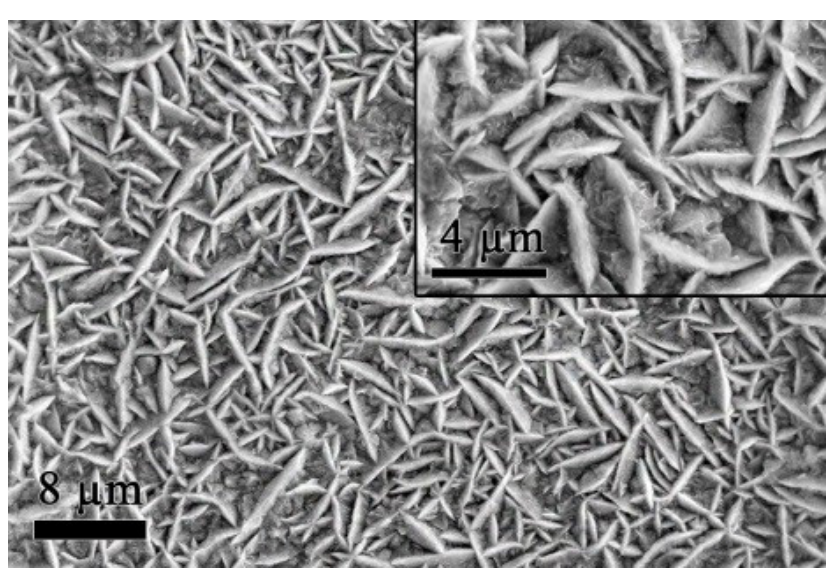

(b)

Figure 3. SEM images of surface of $\mathrm{Co} / \mathrm{SiO}_{2}$ formed at $2 \mathrm{~A} / \mathrm{dm}^{2}$ current density from electrolyte at $1 \mathrm{~g} / \mathrm{dm}^{3} \mathrm{SiO} 2$ nanoparticles: (a) reference sample; $(\mathbf{b})$ irradiated sample.

The tendencies to change the geometry surface of irradiated coatings of $\mathrm{Co} / \mathrm{SiO}_{2}$ positively correlate with data on the study of mass gains per unit area and thickness per time. The comparative relationships between the results of studies of mass rates at different current densities and the composite coatings of $\mathrm{Co} / \mathrm{SiO}_{2}$ from electrolytes containing different $\mathrm{SiO}_{2}$ concentrations are presented in the Figure 4.

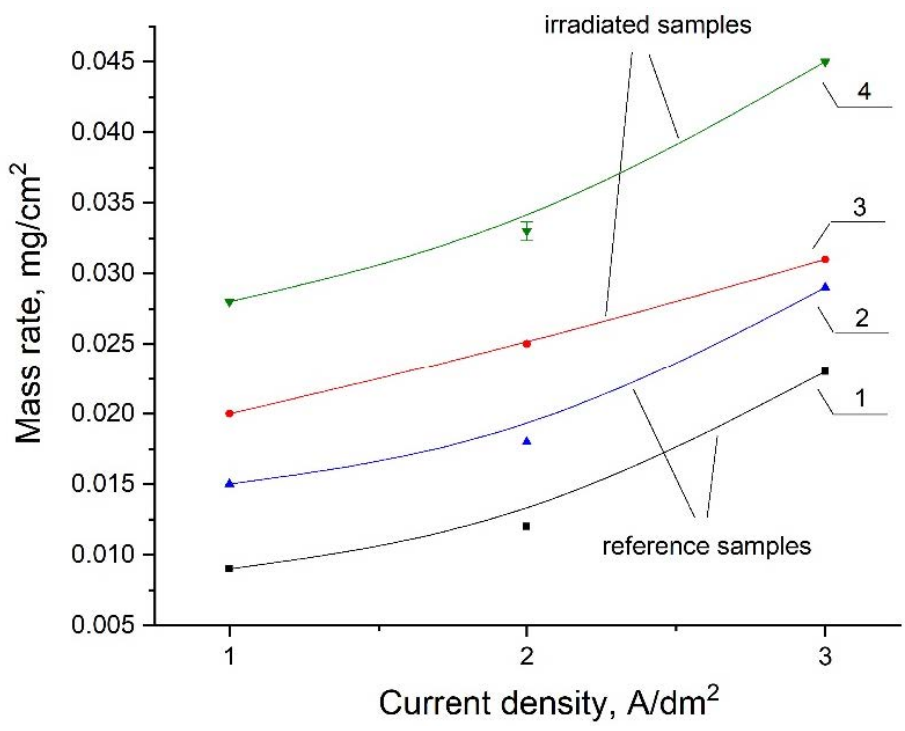

Figure 4. Mass rate in a unit area of the $\mathrm{Co} / \mathrm{SiO}_{2}$ coatings formed at different current densities of 1-3 A/dm²: 1-reference sample, formed from electrolytes at $0.5 \mathrm{~g} / \mathrm{dm}^{3} \mathrm{SiO}_{2} ; 2$-reference sample, formed from electrolytes at $1 \mathrm{~g} / \mathrm{dm}^{3} \mathrm{SiO}_{2} ; 3$-irradiated sample, formed from electrolytes at $0.5 \mathrm{~g} / \mathrm{dm}^{3}$ $\mathrm{SiO}_{2} ; 4$-irradiated sample, formed from electrolytes at $1 \mathrm{~g} / \mathrm{dm}^{3} \mathrm{SiO}_{2}$.

As well already described, the mass gain per unit area increases with increases in a current density, corresponding with Faraday's laws. It is evident that the mass gain of an irradiated deposit is higher when compared with the references samples. The dependencies of thickness over current densities are presented in Figure 5. This analysis shows the correlation between the mass rate of composite coatings with $\mathrm{Co} / \mathrm{SiO}_{2}$. On one 
hand, increases in the mass gain of samples deposited through the use of X-rays is caused by increasing the number of ions that are transferred to the cathode surface through the diffusion layer due to solution radiolysis. On the other hand, the increase is also caused by the change in $\mathrm{pH}$ of electrolyte [27]. In particular, the $\mathrm{pH}$ reduction prevents the formation of coagulants consisting of hydroxide compounds. Hence, the lack of their absorption on the cathode surface promotes the formation of more perfect, compact and non-porous coatings than in the reference sample [24]. From another perspective, an increase in the mass rate of $\mathrm{Co} / \mathrm{SiO}_{2}$ coatings indicates that the incremental increase of the number of nanoparticles included in the base metal matrix is due to increasing the dispersing ability of electrolytes.

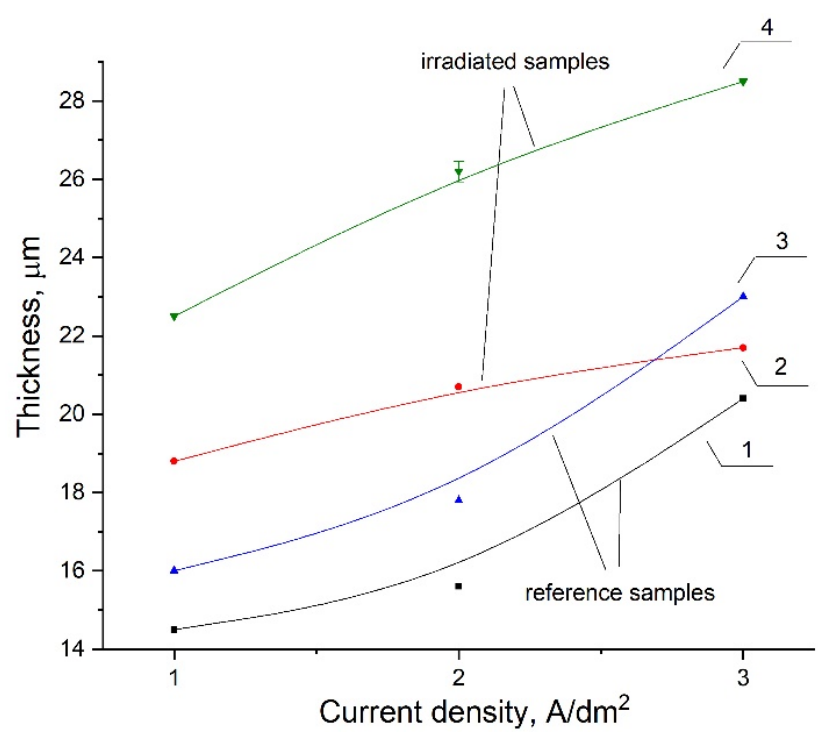

Figure 5. Thickness of $\mathrm{Co} / \mathrm{SiO}_{2}$ formed at different current densities: 1-reference sample formed from electrolytes at $0.5 \mathrm{~g} / \mathrm{dm}^{3} \mathrm{SiO}_{2} ; 2$-irradiated sample formed from electrolytes at $0.5 \mathrm{~g} / \mathrm{dm}^{3} \mathrm{SiO}_{2}$; 3-reference sample formed from electrolytes at $1 \mathrm{~g} / \mathrm{dm}^{3} \mathrm{SiO}_{2} ; 4$-irradiated sample formed from electrolytes at $1 \mathrm{~g} / \mathrm{dm}^{3} \mathrm{SiO}_{2}$.

Figure 5 illustrates the dispersing ability of electrolytes that are used for the deposition $\mathrm{Co} / \mathrm{SiO}_{2}$ coatings at the $0.5 \mathrm{~g} / \mathrm{dm}^{3}$ and $1 \mathrm{~g} / \mathrm{dm}^{3}$ concentration of $\mathrm{SiO}_{2}$ nanoparticles. It is clear in Figure 6 that the X-ray irradiation of electrolytes leads to an increase in the dispersing ability of electrolytes with suspended nanoparticles. As is well known, the dispersing ability of electrolytes points to the uniform distribution of an electric current over the cathode surface, causing the formation of a homogeneous deposit. Thus, it can be surmised that the $\mathrm{X}$-rays' irradiation of electrolytes promotes the formation of compact $\mathrm{Co} / \mathrm{SiO}_{2}$ coatings.

As can be seen in Figure 6, an increase in the concentration of nanoparticles in electrolytes reduces their dispersing ability. Hence, the obtained data allows us to suggest that, since the $\mathrm{SiO}_{2}$ nanoparticles have a high ability to aggregate in aqueous solutions, $\mathrm{X}$-ray irradiation degrades nanoparticles clusters due to an increase in the dispersing ability of electrolytes, contributing to the formation of composite coatings with evenly distributed nanoparticles that have an improved structure and properties.

Figure 7 presents the results of the elemental analysis of composite $\mathrm{Co} / \mathrm{SiO}_{2}$ coatings. It demonstrates the effect of the $\mathrm{X}$-ray on the electroplating cell during the electrodeposition process which promotes the formation of composite coatings with slightly more $\mathrm{SiO}_{2}$ concentration compared with the reference. It should be mentioned that the difference in $\mathrm{SiO}_{2}$ content is less than $0.1 \%$, which is why we can consider this data to be only indicative of a qualitative characteristic. 


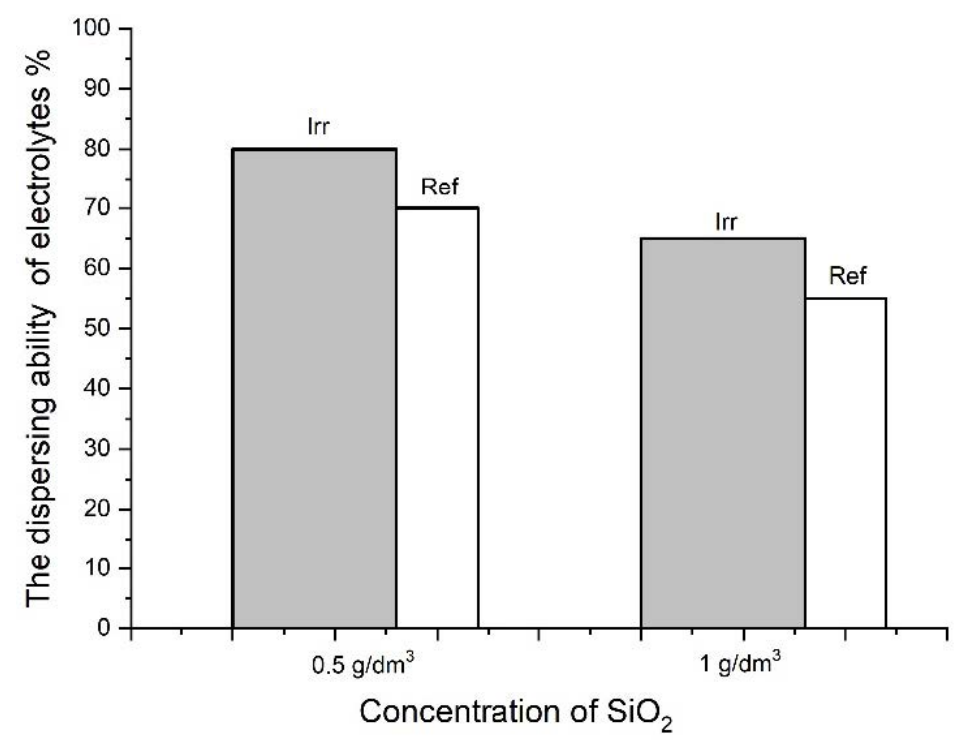

Figure 6. The dispersing ability of irradiated and nonirradiated electrolytes at $0.5 \mathrm{~g} / \mathrm{dm}^{3}$ and $1 \mathrm{~g} / \mathrm{dm}^{3}$ concentration of $\mathrm{SiO}_{2}$ nanoparticles.

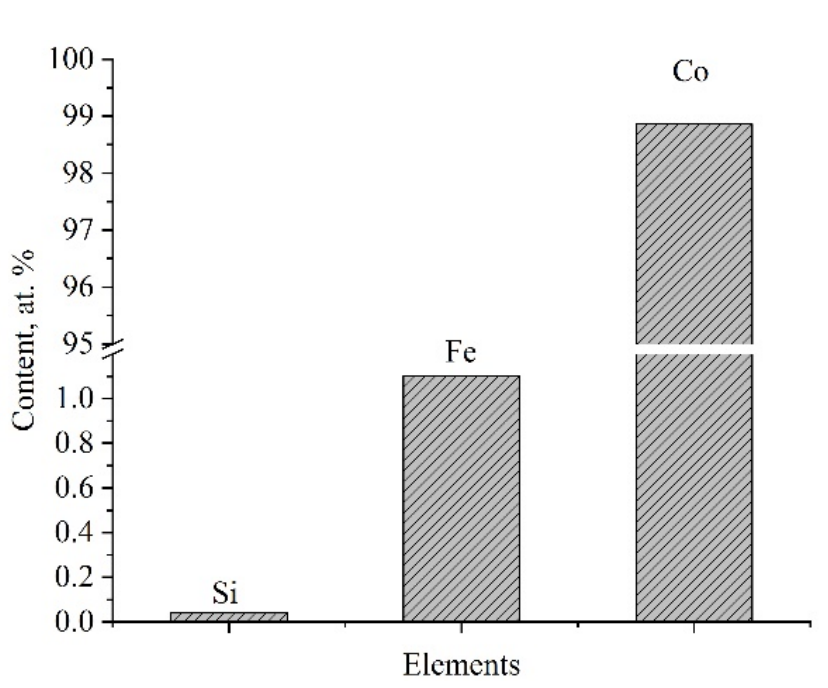

(a)

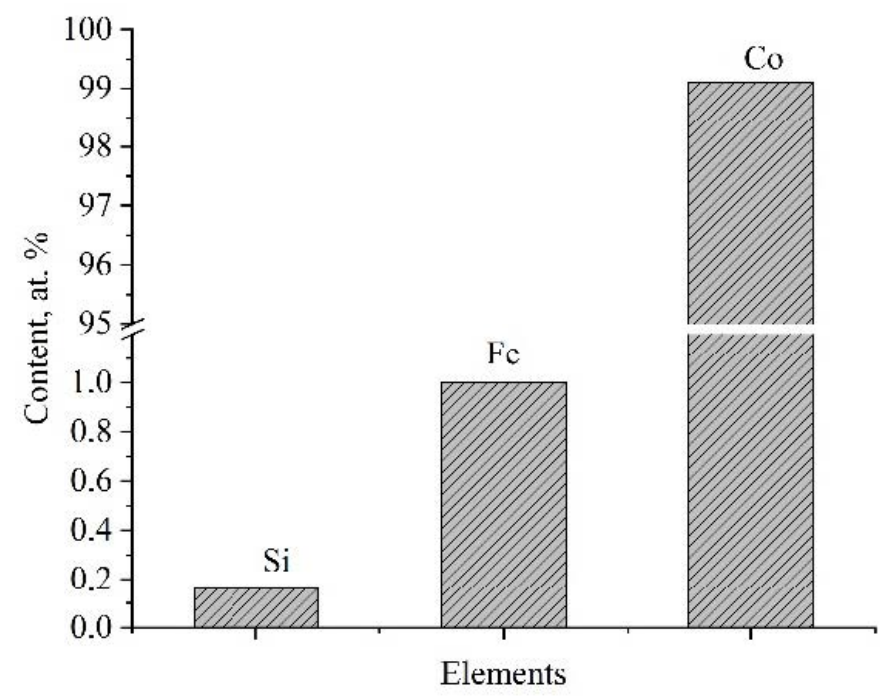

(b)

Figure 7. Elemental composition of $\mathrm{Co} / \mathrm{SiO}_{2}$, formed from the bath at $0.5 \mathrm{~g} / \mathrm{dm}^{3} \mathrm{SiO}_{2}$, under current density of $0.5 \mathrm{~A} / \mathrm{dm}^{2}$ (a) reference sample; (b) irradiated sample.

The obtained date can be explained by suggesting that the X-ray effect on the solution containing nanoparticles is the destruction of nanoparticles clusters due to an increase in the dispersing ability of electrolytes. The obtained data correlate with the study of the mass gain, thickness and dispersing ability. It is worth paying attention to the Fe content in the $\mathrm{Co} / \mathrm{SiO}_{2}$. The Fe content in the coatings formed from electrolytes at $1 \mathrm{~g} / \mathrm{dm}^{3} \mathrm{SiO}_{2}$ (Figure 8) is less than in the deposits formed from electrolytes at $0.5 \mathrm{~g} / \mathrm{dm}^{3} \mathrm{SiO}_{2}$ (Figure 7). The reduction in Fe content can be caused by increasing the thickness and mass gain of the irradiated coatings. As for Fe content in the coatings, Fe can appear due to the preliminary reversal of a direct electric current in the $5 \mathrm{~min}$ period before the electroplating and some amount of Fe ions can be transferred to the solution after the reversal. 


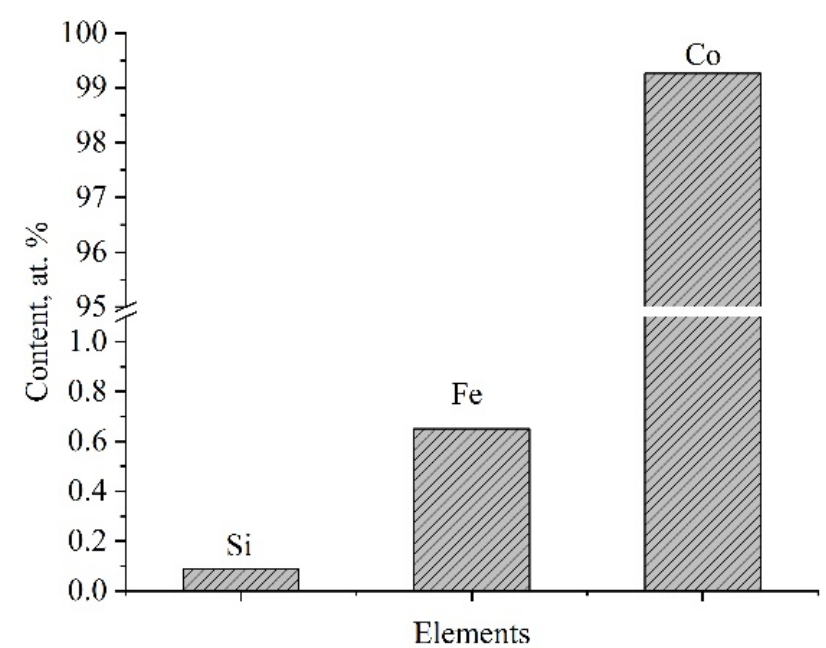

(a)

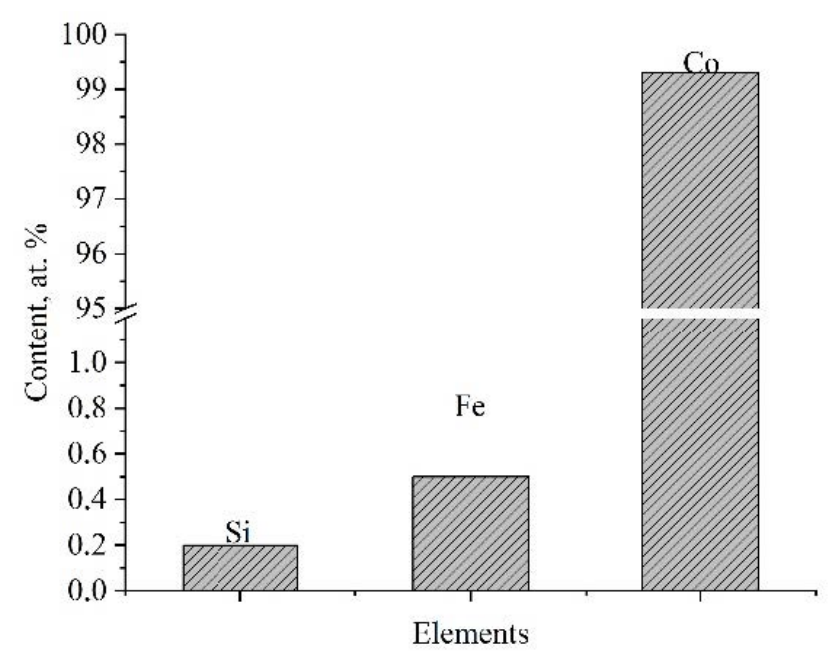

(b)

Figure 8. Elemental composition of $\mathrm{Co} / \mathrm{SiO}_{2}$, formed from the bath at $1 \mathrm{~g} / \mathrm{dm}^{3} \mathrm{SiO}_{2}$, under current density of $1 \mathrm{~A} / \mathrm{dm}^{2}$ (a) reference sample; (b) irradiated sample.

Figure 9 demonstrates the XRD patterns of reference for Co-coatings, Co-coatings obtained in X-rays, and $\mathrm{Co} / \mathrm{SiO}_{2}$ obtained from electrolytes at 0.5 and $1 \mathrm{~g} / \mathrm{dm}^{3} \mathrm{SiO}_{2}$ under irradiation and without. It can be seen in these results that all the investigated samples appear to consist of the Co-phase and oxide phase $\mathrm{CoFe}_{2} \mathrm{O}_{4}$. The phase $\mathrm{CoFe}_{2} \mathrm{O}_{4}$ was formed due to the preliminary reversal of the depositing electric current. According to the low amount of $\mathrm{SiO}_{2}$, there are no any peaks from $\mathrm{SiO}_{2}$. However, it is evident that the addition of some $\mathrm{SiO}_{2}$ into the electrolyte leads to the formation of $\mathrm{CoSiO}_{2}$ coatings with a modified structure, characterized by a crystalline orientation of (110). It should be noted that the intensity of the main peaks of irradiated coatings are higher than the intensity of reference samples. This proves the hypothesis that the X-rays' irradiation of electrolytes during the electroplating process induces the orienting effect on the forming crystal grains of the $\mathrm{Co} / \mathrm{SiO}_{2}$ coatings, due to the radiation transformation in the irradiated electrolyte.

The tendency of the structure of composite coatings $\mathrm{Co} / \mathrm{SiO}_{2}$ to change is what generated the interest in investigating any operational properties that may be produced.

As seen in Figure 10, the microhardness of the irradiated samples markedly increased in comparison with the reference samples. In particular, the difference between the microhardness of the reference samples and irradiated $\mathrm{Co} / \mathrm{SiO}_{2}$ coatings formed from the electrolyte with $\mathrm{SiO}_{2}$ of $0.5 \%$ is around $7 \%$.

Finally, the adhesion tests of the $\mathrm{Co} / \mathrm{SiO}_{2}$ irradiated coatings to the steel substrate showed no separation from the base metal after undergoing scratching tests. It was confirmed that the composite coatings $\mathrm{Co} / \mathrm{SiO}_{2}$ have excellent adhesion, equal to 1 , according to the scale of the scratch method (in which there is a 1-4 scale, where 1 is the best rating), unlike the reference samples which achieved an adhesion of only 2 on the scratch method scale. The structural changes in matter can occur via the primary radiolysis effects as a result of the adsorption radiation by aqueous electrolytes. Hence, these experimental results can be explained from the point of view of radiation chemistry and the radiolysis of aqueous solutions. 


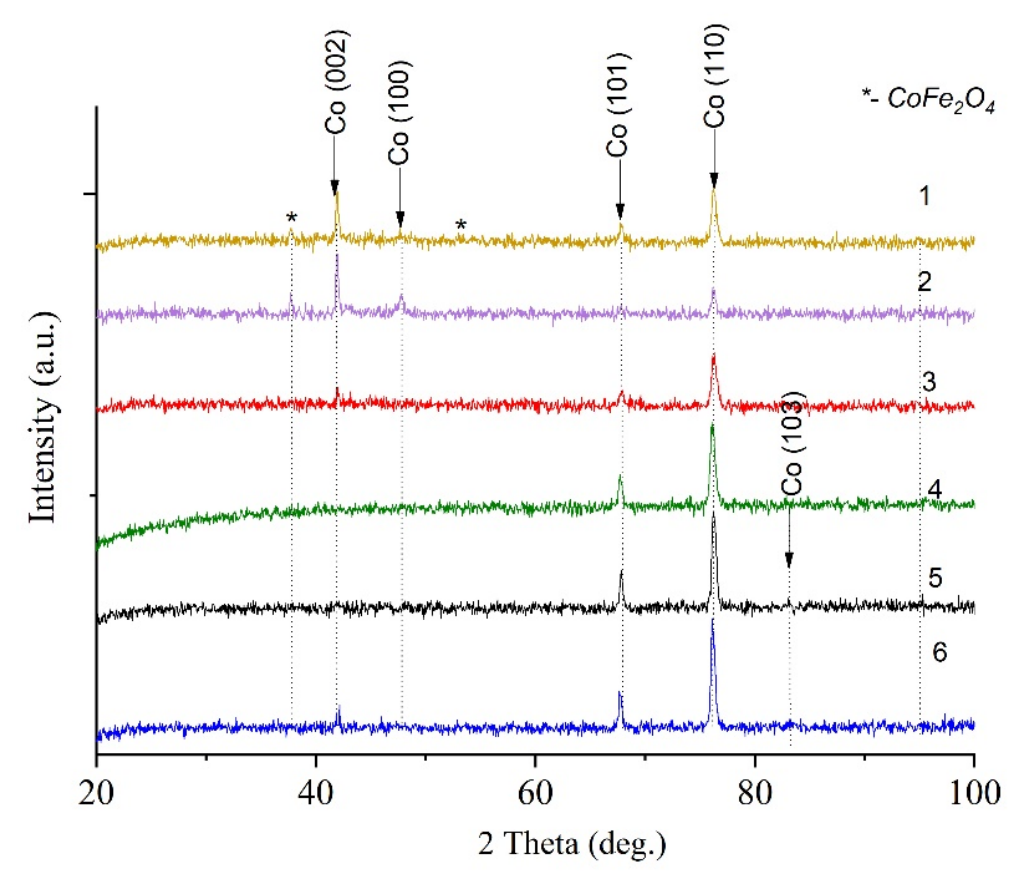

Figure 9. XRD patterns of $\mathrm{CoSiO}_{2}$ coatings deposited in X-rays: 1-reference Co-coating without $\mathrm{SiO}_{2}$, 2-Co-coating, formed under irradiation; $3-\mathrm{CoSiO}_{2}$ deposited from the bath at $0.5 \mathrm{~g} / \mathrm{dm}^{3}$ $\mathrm{SiO}_{2}, 4-\mathrm{CoSiO}_{2}$ deposited from the bath at $0.5 \mathrm{~g} / \mathrm{dm}^{3} \mathrm{SiO}_{2}$ in the X-ray, $5-\mathrm{CoSiO}_{2}$ deposited from the bath at $1 \mathrm{~g} / \mathrm{dm}^{3} \mathrm{SiO}_{2}, 6-\mathrm{CoSiO}_{2}$ deposited from the bath at $1 \mathrm{~g} / \mathrm{dm}^{3} \mathrm{SiO}_{2}$ in the $\mathrm{X}$-ray.

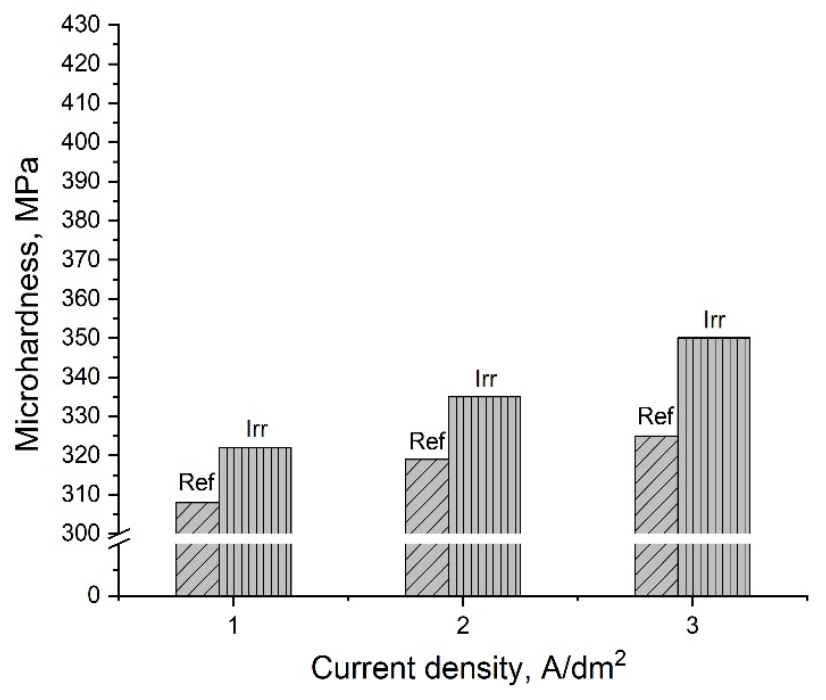

(a)

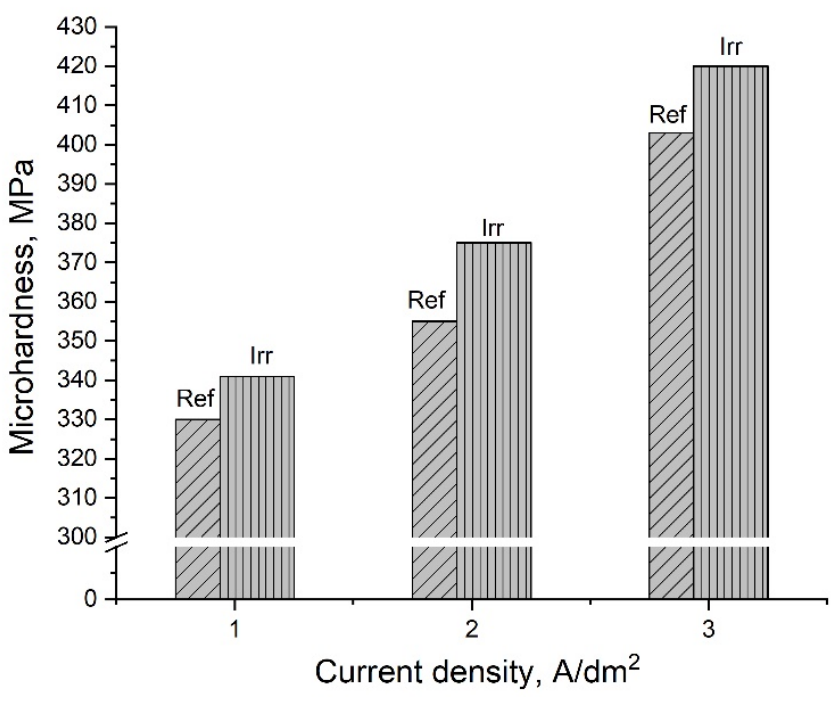

(b)

Figure 10. Microhardness of irradiated (Irr) and non-irradiated (Ref) $\mathrm{Co} / \mathrm{SiO}_{2}$ formed at current densities of $1-3 \mathrm{~A} / \mathrm{dm}^{2}$ from electrolyte with $\mathrm{SiO}_{2}$ nanoparticles of $0.5 \mathrm{~g} / \mathrm{dm}^{3}(\mathbf{a})$ and $1 \mathrm{~g} / \mathrm{dm}^{3}(\mathbf{b})$.

\section{Conclusions}

The results of these extensive investigations into the effect of $\mathrm{X}$-rays on the electroplating process of composite coatings $\mathrm{Co} / \mathrm{SiO}_{2}$ from an aqueous solution demonstrate an increase in the dispersing ability of electrolytes containing $\mathrm{SiO}_{2}$ nanoparticles, mass gain and thickness per time under irradiation. This is due to the intensification of diffusion in the electrolyte through the products of radiolysis. 
This study demonstrated that the effect of the bath by X-rays during the electroplating process of the $\mathrm{Co} / \mathrm{SiO}_{2}$ coatings results in the orienting effect on the formation of crystal grains, allowing for the creation of dense, morphologically uniform coatings with increased hardness and improved adhesion.

In conclusion, the authors of this paper have found enough evidence to find that the electroplating of composite coatings under the effect of $X$-rays makes it possible to achieve a technical result that consists of an increase in the dispersing ability of electrolytes, containing nanoparticles, reducing aggregation, and increasing the sedimentation stability of nanoparticles This allows for modification of the microstructure and enhancement of the performances of properties of composite coatings with included $\mathrm{SiO}_{2}$ nanoparticles.

Author Contributions: Conceptualization, N.V. and T.N.K.; methodology, N.V.; software, N.V., W.E., V.B. and P.O.; validation, N.V. and V.A.; formal analysis, N.V., V.A. and T.N.K.; investigation, N.V., W.E. and V.A.; resources, N.V., W.E. and T.N.K.; data curation, W.E., V.B. and P.O.; writing-original draft preparation, N.V.; writing-review and editing, T.N.K.; visualization, T.N.K.; supervision, N.V.; funding acquisition, V.B., P.O. and T.N.K. All authors have read and agreed to the published version of the manuscript.

Funding: The research was supported by the Ministry of Education of the Republic of Belarus and by the subsidy of the Ministry of Education and Science (Poland) for the Lublin University of Technology as funds allocated for scientific activities in the scientific discipline of Automation, Electronics and Electrical Engineering-grants: FD-20/EE-2/701, FD-20/EE-2/703 and FD-20/EE-2/705.

Institutional Review Board Statement: Not applicable.

Informed Consent Statement: Not applicable.

Data Availability Statement: Not applicable.

Conflicts of Interest: The author declare no conflict of interest.

\section{References}

1. Milaniak, N.; Laroche, G.; Massines, F. Atmospheric-pressure plasma-enhanced chemical vapor deposition of nanocomposite thin films from ethyl lactate and silica nanoparticles. Plasma Process. Polym. 2020, 18, e2000153. [CrossRef]

2. Liu, X.C.; Fecko, P.; Fohlerova, Z.; Karasek, T.; Pekarek, J.; Neuzil, P. Parylene micropillars coated with thermally grown SiO 2 . J. Vac. Sci. Technol. B 2020, 38, 063001. [CrossRef]

3. Koltunowicz, T.N. Inductive type properties of $\mathrm{FeCoZr}-\mathrm{CaF}_{2}$ and FeCoZr-PZT nanocomposites. J. Mater. Sci. Mater. Electron. 2015, 26, 6450-6457. [CrossRef]

4. Svito, I.; Fedotova, J.A.; Milosavljević, M.; Zhukowski, P.; Koltunowicz, T.N.; Saad, A.; Kierczynski, K.; Fedotov, A.K. Influence of sputtering atmosphere on hopping conductance in granular nanocomposite $(\mathrm{FeCoZr})_{\mathrm{x}}\left(\mathrm{Al}_{2} \mathrm{O}_{3}\right)_{1-\mathrm{x}}$ films. J. Alloy. Compd. 2015, 615 (Suppl. 1), S344-S347. [CrossRef]

5. Zhukowski, P.; Kołtunowicz, T.N.; Fedotova, J.A.; Larkin, A.V. An effect of annealing on electric properties of nanocomposites $(\mathrm{CoFeZr})_{\mathrm{x}}\left(\mathrm{Al}_{2} \mathrm{O}_{3}\right)_{1-\mathrm{x}}$ produced by magnetron sputtering in the atmosphere of argon and oxygen beyond the percolation threshold. Prz. Elektrotechniczny 2010, 86, 157-159.

6. Shang, H.; Fu, J.; Xie, C.; Li, Z.; Chen, D. Improving stress stability in low-pressure chemical vapor deposited silicon dioxide films by ion implantation. Thin Solid Film. 2016, 598, 103-108. [CrossRef]

7. Sourani, F.; Enayati, M.H.; Ashrafizadeh, F.; Sayyedan, F.S.; Chu, P.K. Enhancing surface properties of $(\mathrm{Fe}, \mathrm{Cr}) \mathrm{Al}_{-} \mathrm{Al}_{2} \mathrm{O}_{3}$ nanocomposite by oxygen ion implantation. J. Alloy. Compd. 2021, 853, 156892. [CrossRef]

8. Koltunowicz, T.N.; Zukowski, P.; Bondariev, V.; Fedotov, A.K.; Svito, I.; Fedotova, J.; Saad, A. Voltage and current resonance in nanocomposite $(\mathrm{FeCoZr})_{\mathrm{x}}\left(\mathrm{CaF}_{2}\right)_{(100-x)}$ produced by ion-beam sputtering in pure argon atmosphere. Acta Phys. Pol. A 2015, 128, 897-900. [CrossRef]

9. Becker, M.; Benz, S.L.; Chen, L.; Polity, A.; Klar, P.J.; Chatterjee, S. Controlled thin-film deposition of alpha or beta Ga ${ }_{2} \mathrm{O}_{3}$ by ion-beam sputtering. J. Vac. Sci. Technol. A 2020, 38, 063412. [CrossRef]

10. Sun, K.X.; Zhang, S.Y.; Wasa, K.; Shui, X.J. Characterization of La-doped $x \mathrm{BiInO}_{3}(1-\mathrm{x}) \mathrm{PbTiO}_{3}$ piezoelectric films deposited by the radio-frequency magnetron sputtering method. Chin. Phys. Lett. 2016, 33, 064301. [CrossRef]

11. Guo, L.; Zhao, M.; Zhuang, D.; Gong, Q.; Tan, H.; Cao, M.; Ouyang, L. A study on phase transformation of SnOx thin films prepared by reactive magnetron sputtering. Mater. Sci. Semicond. Process. 2016, 46, 35-38. [CrossRef]

12. Hoppe, C.; Mitschker, F.; Butterling, M.; Liedke, M.O.; de los Arcos, T.; Awakowicz, P.; Wagner, A.; Grundmeier, G. Characterisation of micropores in plasma deposited $\mathrm{SiO}(\mathrm{x})$ films by means of positron annihilation lifetime spectroscopy. J. Phys. Appl. Phys. 2020, 53, 475205. [CrossRef] 
13. Singh, J.; Chatha, S.S.; Singh, H. Characterization and corrosion behavior of plasma sprayed calcium silicate reinforced hydroxyapatite composite coatings for medical implant applications. Ceram. Int. 2021, 47, 782-792. [CrossRef]

14. Ali, G.A.M.; Yusoff, M.M.; Ng, Y.H.; Lim, H.N.; Chong, K.F. Potentiostatic and galvanostatic electrodeposition of manganese oxide for supercapacitor application: A comparison study. Curr. Appl. Phys. 2015, 15, 1143-1147. [CrossRef]

15. Aghazadeh, M. Cathodic Cathodic Electrochemical Deposition of Nanostructured Metal Oxides/Hydroxides and their Composites for Supercapacitor Applications: A Review. Anal. Bioanal. Electrochem. 2019, 11, 211-266.

16. Ilyin, V.; Semyonichev, V.; Salakhova, R.; Naletov, B.; Tikhoobraz, A. Nickel-plating electrolyte. RU Patent 2,449,063, 5 April 2011.

17. Pogrebnjak, A.D.; Bagdasaryan, A.A.; Pshyk, A.; Dyadyura, K. Adaptive multicomponent nanocomposite coatings in surface engineering. Phys. Uspekhi 2017, 60, 586-607. [CrossRef]

18. Müller, T.; Grimwood, J.; Bachmaier, A.; Pippan, R. Electrodeposition of Fe-C Alloys from Citrate Baths: Structure, Mechanical Properties, and Thermal Stability. Metals 2018, 8, 363. [CrossRef]

19. Misaelides, P.; Hatzidimitriou, A.; Noli, F.; Pogrebnjak, A.D.; Tyurin, Y.N.; Kosionidis, S. Preparation, characterization, and corrosion behavior of protective coatings on stainless steel samples deposited by plasma detonation techniques. Surf. Coat. Technol. 2004, 180, 290-296. [CrossRef]

20. Jar-Mukhamedov, S. Method for electrodeposition of composite coatings and plant for its embodiment. RU Patent 2,109,855, 8 July 1991.

21. Pikayev, A. Radiolysis of Gases and Liquids. Available online: https://www.researchgate.net/publication/285195827_Radiolysis_ of_Gases_and_Liquids (accessed on 11 August 2021).

22. Valko, N.; Moroz, N. Modification of a structure of the CoNiFe alloys by the X-ray irradiation. In Proceedings of the 9th International Conference New Electrical and Electronic Technologies and their Industrial Implementation, Zakopane, Poland, 23-26 June 2015; pp. 11-13.

23. Koltunowicz, T.N.; Zhukowski, P.; Fedotova, J.A.; Bayev, V.G.; Streltsov, E.A.; Baran, L.V. Electrochemically Deposited Cobalt Nanoarrays in $\mathrm{SiO}_{2} / \mathrm{n}$-Si Templates Produced by Swift Heavy Ion-Induced Modification Technology. Acta Phys. Pol. A 2013, 123, 929-931. [CrossRef]

24. Valko, N.; Kasperovich, A.; Koltunowicz, T.N. Forming a structure of the CoNiFe alloys by X-ray irradiation. Funct. Mater. Lett. 2019, 11, 1850044. [CrossRef]

25. Kucera, M.; Gutten, M.; Simko, M.; Sebok, M.; Korenciak, D.; Jarina, R.; Pitonak, M. Electromagnetic Compatibility and Radiation Analysis in Control Room. Meas. Sci. Rev. 2019, 19, 126-131. [CrossRef]

26. GOST 9.302-88 Unified System of Protection against Corrosion and Aging. Metal and Non-Metal Coatings. Inorganic Control Methods. Available online: https:/ /internet-law.ru/gosts/gost/19600 (accessed on 3 July 2021).

27. GOST 9.309-86 Galvanic Coatings. Determination of the Ability of Electrolytes in a Dispersive Coating. Available online: http:/ / gostrf.com/normadata/1/4294850/4294850372.pdf (accessed on 3 July 2021). 